The DOE SunShot Initiative is a collaborative national initiative to make solar energy technologies costcompetitive with other forms of energy by reducing the cost of solar energy systems by about $75 \%$ by the end of the decade. Reducing the total installed cost for utility-scale solar electricity to roughly 6 cents per kilowatt hour without subsidies will result in rapid, large-scale adoption of solar electricity across the United States. Reaching this goal will re-establish American technological leadership, improve the nation's energy security, and strengthen U.S. economic competitiveness in the global clean energy race.

SunShot will work to bring down the full cost of solar including the costs of solar cells and installation by focusing on four main pillars:

1. Technologies for solar cells and arrays that convert sunlight to energy;

2. Electronics that optimize the performance of the installation;

3. Improvements in the efficiency of solar manufacturing processes; and

4. Installation, design, and permitting for solar energy systems.

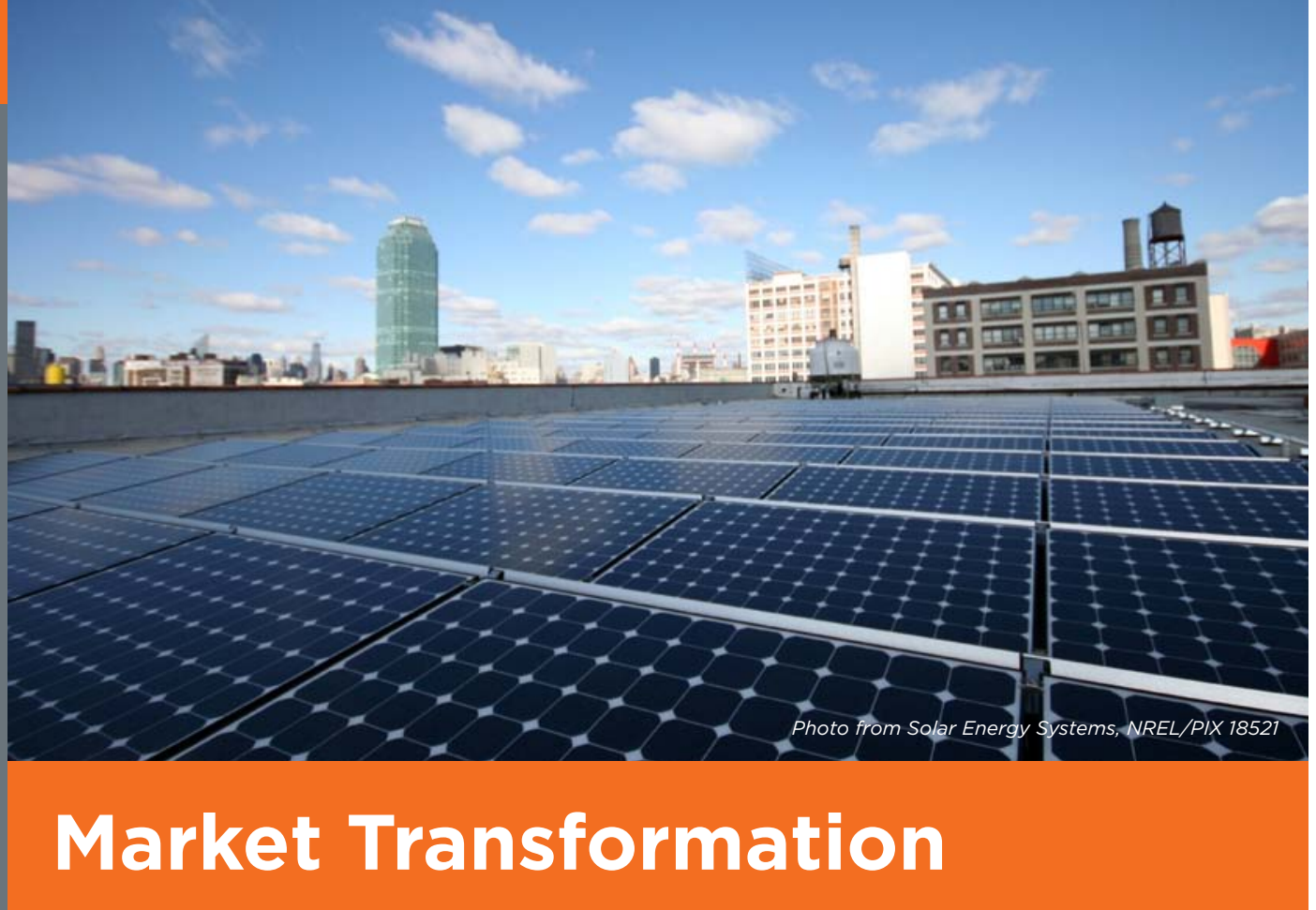

Through the SunShot Initiative, the U.S. Department of Energy (DOE) works with manufacturers, communities, states, utilities, and other partners to enable the solar market by reducing non-hardware balance-of-system (BOS) costs, developing a skilled workforce, and eliminating market barriers to widespread adoption of solar technologies. Going beyond traditional research and development $(\mathrm{R} \& \mathrm{D})$, market transformation activities are critical to helping the United States achieve the SunShot goal of making large-scale solar energy systems cost-competitive with other energy sources before the end of the decade.

\section{Meeting Challenges}

In addition to increasing local manufacturing and distribution, the domestic solar market faces other significant challenges. These range from inconsistent utility practices and restrictive regulations and policies to complex, expensive installation and financing mechanisms, and a shortage of well-trained solar installers. Through a comprehensive portfolio of analysis, stakeholder engagement, and partnerships, the DOE is successfully confronting market transformation challenges head on.

\section{Driving Local Innovation}

A national effort to make clean, solar electricity cost-competitive for American communities, DOE's rooftop solar challenge - Race to the Rooftop - aims to drive significant reductions in the administrative costs for photovoltaic (PV) systems. This national competition will engage diverse teams of local and state governments along with utilities, installers, nongovernment organizations, and other critical stakeholders to make solar energy more accessible and affordable for homeowners and businesses. To learn more, visit solar.energy.gov/challenge.

\section{Supporting Strong State Markets}

Through innovative trainings, workshops, and technical assistance programs, DOE directly engages with state decision makers. DOE has developed a customizable turnkey training curriculum, covering a range of technical and non-technical topics, for legislators, utility regulators, and state energy office directors, as well as all of their staff. In 2011, DOE and 
the national labs led a variety of such trainings for policymakers in Hawaii, California, and the Northeast and Southeast regions. DOE's Solar Technical Assistance Team (STAT) capitalizes on the expertise of DOE staff, national labs, and other partners to provide rapid-response technical assistance for states' most pressing solar implementation questions.

DOE also partners with state public utilities commissions to provide technical assistance on targeted, longer-term projects.

\section{Removing Barriers to Utility-Scale Solar}

DOE works directly with federal agencies, including the Department of the Interior, the Department of Defense, and the Council on Environmental Quality, to streamline and accelerate siting and permitting for large projects. In addition, DOE funds the development of tools, which facilitate utility-scale solar project siting.

DOE also collaborates with utilities and their stakeholders to identify and address the unique obstacles facing utilities as they integrate solar onto the transmission and distribution systems. Recent examples include peer-to-peer workshops, participation in transmission planning efforts in the West, and sponsorship of the Solar Electric Power Association's annual Utility Solar Conference.

\section{Strengthening a Skilled Solar Workforce}

A well-trained workforce is critical to support a successful solar market. High-quality installations improve system performance at a lower cost, driving consumer demand for solar technologies. In 2009, DOE established the Solar Instructor Training Network to increase the quality, consistency, and availability of instruction

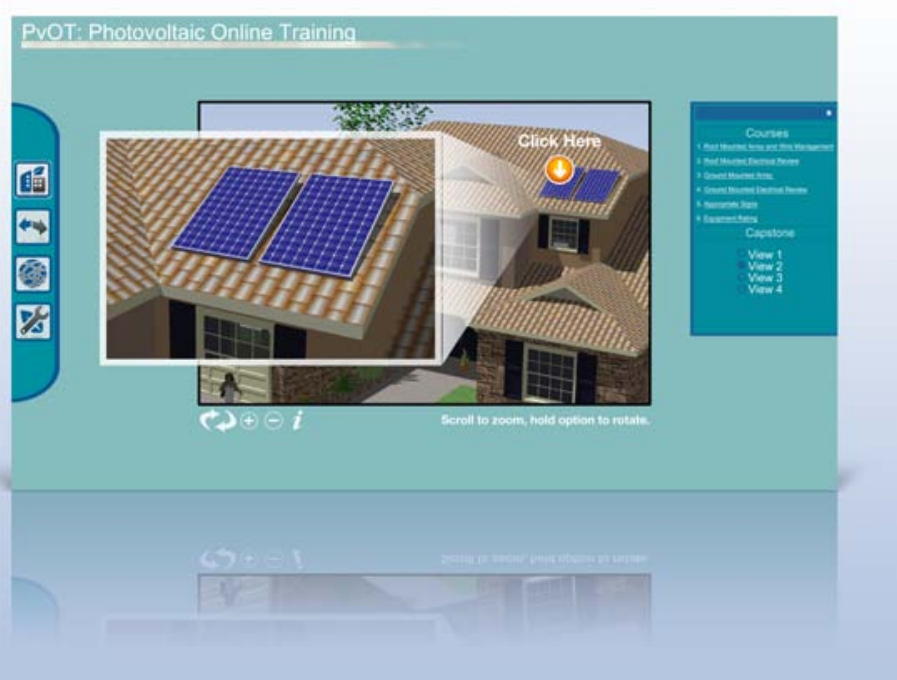

Through its Solar Instructor Training Network, DOE is funding the development of "PVOT" - a comprehensive online training system for building, fire, and safety code officials, which will be available in early 2012 .

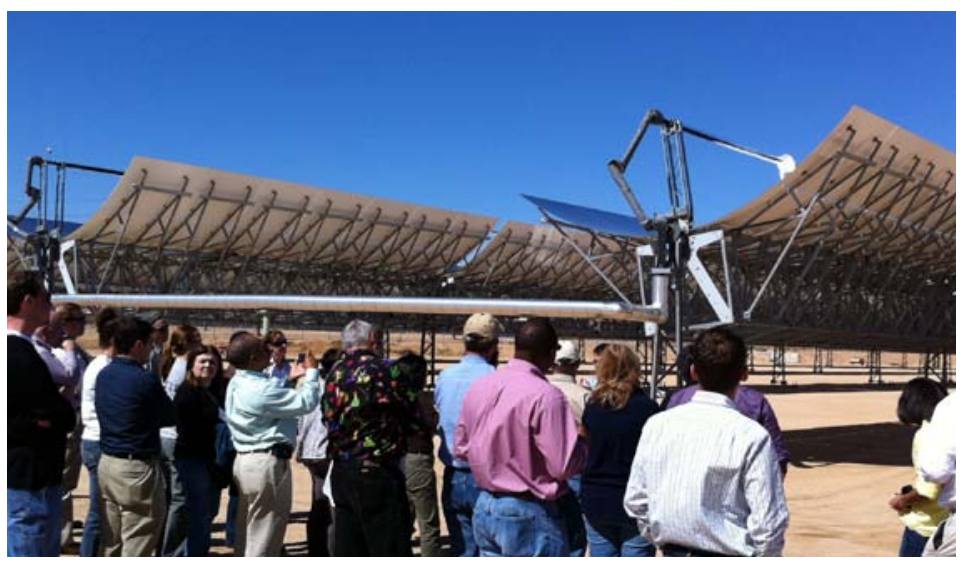

In October 2010, DOE partnered with the National Association of Regulatory Utility Commissioners to organize a day-long tour of utility-scale solar energy facilities as part of a 2-day workshop on integrating renewables onto the grid for utility regulators. Photo credit by John Miller

in PV installation and design. Eight Regional Training Providers, guided by a national administrator, are strengthening local training programs in emerging solar markets; training master instructors; supplying PV training equipment; and developing best practices to align training and employment. Over the life of the five-year project, up to 500 instructors - representing more than 260 institutions and 22 labor training centers - will be trained across all PV-related disciplines, including engineering, architectural design, and energy and environmental degree programs. In addition, online training tools are in development that will deliver comprehensive, credible resources for code officials, as well as educational institutions and students.

\section{Providing Solar Market Insights}

DOE supports critical data gathering and analysis to track solar market development, benchmark key non-hardware system costs (such as permitting, interconnection, and inspection), and provide independent insight on emerging issues. DOE publishes timely analyses on solar economics, installation trends, labor market trends, and innovative financing approaches, among other topics.

\section{Solar Program Priorities}

Market Transformation is one of four key focus areas for DOE's Solar Program, along with Photovoltaics, Concentrating Solar Power, and Systems Integration. Together, this multifaceted approach supports the SunShot Initiative - a collaborative national effort to make solar energy cost-competitive with other forms of energy before the end of the decade. To learn more about the SunShot Initiative, visit energy.gov/sunshot.

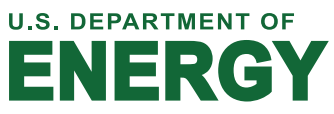

energy.gov

DOE/GO-102011-3368 • October 2011 